\title{
Effect of Drying Methods on Physicochemical Parameters of Different Red Beetroots (Beta vulgaris L.) Species
}

\author{
Dóra Székely, Klaudia Vidák', Diána Furulyás¹, Ákos Ribárszki', Mónika Stéger-Máté1 \\ ${ }^{1}$ Department of Food Preservation, Faculty of Food Science, Szent István University, H-1118 Budapest, Villányi út 29-43, Hungary \\ ${ }^{*}$ Corresponding author, e-mail: babinszky-szekely.dora@etk.szie.hu
}

Received: 10 September 2018, Accepted: 05 November 2018, Published online: 22 January 2019

\begin{abstract}
The aim of this work was to study the influence of atmospheric, vacuum and microwave vacuum drying methods on the quality of dried beetroots. Three different red beetroot species ('Alto F1', 'Cylindra', 'Detroit') were chosen in this study. The microwave vacuum method reduced the total time of drying and decreased the shrinkage compared to the other drying methods. The quality of the dehydrated material was described by its color change, antioxidant capacity, total polyphenol, betacyanin, betaxanthin and each phenolic acids content. The attempts were made to suggest the microwave vacuum method for red beetroot samples as a gentle drying technology to reach a special texture that is favoured by costumers. During the experiments relevant differences could be observed between the investigated beetroot species on the effect of different drying methods. According to the examined parameters the 'Cylindra' species proved the most appropriate beetroot variety for microwave vacuum drying. Based on the results, the combined methods with hot-air at $60{ }^{\circ} \mathrm{C}$ followed by microwave vacuum finish drying was the most suitable assay to preserve the investigated parameters in the highest amount.
\end{abstract}

Keywords

beetroot, drying, color content, antioxidant capacity, polyphenol content

\section{Introduction}

Nowadays the consumers expect the products to have a long shelf life besides their ability to be able to be prepared and consumed quickly as well as these products are also expected to contain as much healthy ingredients as the fresh ones. These requirements resulted in the future improvement of some technology such as vacuum and microwave drying.

Microwave vacuum drying is such a gentle drying process that removes water quickly and efficiently from foods. This technology is characterized by a faster drying rate relative to conventional drying methods. Intensive heating by microwaves and low boiling point generated by the vacuum cause the substances to be dried for a short period of time and at relatively low temperatures, which helps to maintain a high level of healthy nutrition [1]. The main difference between convective and microwave vacuum drying is the type of energy supply used. In convective drying the necessary energy is provided by hot-air flowing around the sample. In microwave vacuum drying heat is generated in the whole volume of the material due to high-frequency polarization of the dipolar molecules of water [2]. During the process the moisture content in the fresh material is instantaneously vaporized, which impinges on the product thanks to the internal expansion force. After the rapid evaporation of the moisture content the product hardens and gets a spicy crunchy texture. Previous research has shown this is a very attractive organoleptic characteristic for consumers [3]. Microwave vacuum drying reduces the drying time, which is important because high temperatures and long drying times darken the final product and also, affect negatively on the quality $[4,5]$. Several studies demonstrated that the microwave vacuum treated products have favourable organoleptic properties and its crispy, puffed structure is favoured by consumers towards unpleasant hard surface which developed during the hotair drying [6]. Ferenczi et al. [7] investigated the quality of dried apple products. Their results showed that the quality of the product made by microwave vacuum drying combined with hot- air pre-drying is higher than hot-air dried ones. Dermelj et al. [8] found the microwave vacuum 
drying for suitable method to dehydrate herbal extracts because the drying was faster and more chlorophyll content remained in the samples than in the hot-air dried ones.

\section{Materials and methods}

\subsection{Plant materials}

During the experiment the spring sowing of 'Alto F1', 'Cylindra' and 'Detroit' species was carried out in conventional soil at the Experimental and Research Farm of Department of Vegetables and Mushroom Growing (Szent István University). During the cultivation in 2016 of beetroots were not treated except the mechanical weed control and irrigation. The sampling took place at 10 different points of the production area for all three beetroot species. The investigated beetroot samples originated from only one production area in order to have variations induced by the drying process and different beetroot species, not by the season, year and place of cultivation.

\subsection{Drying process}

After the harvest, the leaves and peel of the beetroots were removed. The samples were cut into $2 \mathrm{~mm}$ thick slices and then cut into $1 * 1 \mathrm{~cm}^{2}$ square pieces with slicer. The samples were pre-dried for $1.5,1$ and 0.75 hour at atmospheric pressure in LP-322 type oven at $40{ }^{\circ} \mathrm{C}, 60{ }^{\circ} \mathrm{C}$ and $80{ }^{\circ} \mathrm{C}$. The pre-dried samples at difference temperatures were divided into three equal portions. Three replications were taken for each experiment to get an average values. Pre-treated samples of $100 \mathrm{~g}$ were dried by the seven different drying methods, while the moisture content reduced below $10 \%$. By the first method the samples were dried on atmospheric pressure at $60{ }^{\circ} \mathrm{C}$ during the whole process (A60). By the further three methods the drying process was carried out in MEMMERT-VO type vacuum-drier at 40,50 and $60^{\circ} \mathrm{C}$ (V40; V50; V60) at 50 mbar after the pre-drying at $60^{\circ} \mathrm{C}$. The energy required for the different drying methods can be seen on the Table 1. Ferenczi et al. [9] investigated the effect of microwave vacuum drying for Jonathan apple with $65 \%$ initial dry matter content. In case of this pre-dried material the 13 magnetron minutes treatment results $0 \%$ burn rate, so based on the applied model it means $3315 \mathrm{~J} \mathrm{~g}^{-1}$ energy spread. Follow the preliminary experiments $2880 \mathrm{~J} / \mathrm{g}$ energy distribution was found to be suitable for beetroot samples with moisture content below $30 \%$, which meant 10 minutes of $300 \mathrm{~W}$ and 3 minutes of $600 \mathrm{~W}$ treatment. So in case of the other further three methods a LABOTRON microwave drier were applied with these parameters after the pre-drying at 40,60 and $80^{\circ} \mathrm{C}$ (MV40; MV60; MV80).
Table 1 Use of energy for each drying method

\begin{tabular}{lccc}
\hline $\begin{array}{l}\text { Drying } \\
\text { methods }\end{array}$ & $\begin{array}{c}\text { Drying } \\
\text { time (min) }\end{array}$ & $\begin{array}{c}\text { Energy used during } \\
\text { drying }\left(\mathrm{J} \mathrm{g}^{-1}\right)\end{array}$ & $\begin{array}{c}\text { Specific energy } \\
\text { consumption } \\
\left(\mathrm{j} \mathrm{g}^{-1}\right) \text { per minute }\end{array}$ \\
\hline A60 & 90 & 8100 & 90 \\
V40 & 105 & 13500 & 129 \\
V50 & 90 & 10800 & 120 \\
V60 & 90 & 10800 & 120 \\
MV40 & 103 & 16950 & 150 \\
MV60 & 73 & 13350 & 183 \\
MV80 & 58 & 12000 & 206 \\
\hline
\end{tabular}

\subsection{Analytical methods}

The color measurement was realized with Konica Minolta CR 400 type handheld digital color measuring device which is on the base of the CIELab system. The $L^{*}$ (lightness factor), the $a^{*}$ (the transition from red to green) and the $b^{*}$ (from blue to yellow) were measured. To evaluate the change in color between two samples, the total color difference parameter $\Delta E$ was used according to Eq. (1):

$\Delta E=\sqrt{\left(L_{F}^{*}+L_{D}^{*}\right)^{2}+\left(a_{F}^{*}+a_{D}^{*}\right)^{2}+\left(b_{F}^{*}+b_{D}^{*}\right)^{2}}$

where indices $F$ and $D$ donate the fresh and dried material, respectively. The higher $\Delta E$ value means bigger difference between the color of the fresh and dried materials.

During the extraction $2 \mathrm{~g}$ of each dried sample was dissolved in $10 \mathrm{ml}$ of $20 \%$ methanol. The mixture was stirred in a shaker at $800 \mathrm{rpm}$ for $10 \mathrm{~min}$ and homogenate was centrifuged at $6000 \mathrm{rpm}$ for $10 \mathrm{~min}$. The spectrometric measurements were carried out with Hitachi U-2900 equipment.

Total polyphenol content was investigated using FolinCiocalteu's reagent according to the method of Singleton and Rossi [10]. Absorbance was monitored spectrophotometrically at $760 \mathrm{~nm}$, and the content of soluble polyphenols was calculated from standard curve based on gallic acid (GA) concentrations. The results were expressed in mg GA g ${ }^{-1}$ dried weight (DW).

For the antioxidant capacity determination, the experiment was carried out by means of the FRAP method proposed by Benzie and Strain [11]. FRAP assay was conducted spectrophotometrically at $593 \mathrm{~nm}$. FRAP value was expressed as ascorbic acid (AA) equivalents, $\mathrm{mg} \mathrm{AA} \mathrm{g}^{-1} \mathrm{DW}$.

Determination of betacyanin and betaxanthin content was performed according to the spectrophotometric method by Castellar et al. [12] and Stintzing et al. [13]. The absorbency of the sample solutions diluted to $2 \%$ and measured on $535 \mathrm{~nm}$ and $484 \mathrm{~nm}$. Destilled water was used for blank samples. The results were provided in $\mathrm{mg}$ $\mathrm{g}^{-1}$ betacyanin DW and $\mathrm{mg} \mathrm{g}^{-1}$ betaxantin DW dimension. 
The phenolic acids content was measured as described previously by Székely et al. [14]. The separation of the phenolic components was done with Shimadzu HPLC instrument which consists of a gradients pump (LC 10), an UV-Vis detector (SDP-10A), a degasser (DGU-20A9), a column-thermostating unit (CTO-10A), a control unit (CBM20A), and a computer software (LC Solution Software) that makes the processing and analysis of data easier. The reversed phase C18 column (Supelco, 250x4.6 mm i.d, $5 \mu \mathrm{m}$ ) was used for the HPLC investigation of flavonoids. The measured values were compared to the different phenolic standards (chologenic acid, rutin, hydroxyl cinnamic acid and querecetin) and the results were expressed as $\mathrm{mg} \mathrm{g}^{-1}$ on a dry weight basis.

The moisture content was determined by RADVAG MAC-50 equipment.

\subsection{Sensory evaluation}

The sensory tests were conducted in the Sensory Laboratory of Szent István University, Faculty of Food Science. The data were collected and evaluated with the ProfiSens software [15]. The electronic score sheet was built using unstructured line scales and comment fields. The test was realized with 14 assessors. To understand and carry out the tests the judges received training on the use of sensor software and scales.

\subsection{Statistical evaluation}

Differences between total polyphenol content, antioxidant capacity, the betacyanin, betaxanthin content of dried samples were evaluated by Student t-test at 95\% confidence. One-way ANOVA was used for the sensory analysis on the 0.05 confidence level.

\section{Results and discussion}

\subsection{Change of investigated parameters}

During the different drying methods the color difference parameters are between 2.20 and 13.39 (Fig. 1) related to the fresh samples. This means that, the color change in the dried samples can be noticed in all cases. In additional the $\Delta E$ parameters of the microwave vacuum dried samples are higher (5.06-13.39). Musielak and Kierca [16] reported that, the color difference parameters were between 8 and 22 for microwave vacuum dried beetroot samples. It can be seen on the Fig. 1, the 'Cylindra' samples had lower color difference parameters than the values of 'AltoF1' and 'Detroit' samples. The total polyphenol contents (TPC) were found to be higher with the microwave vacuum

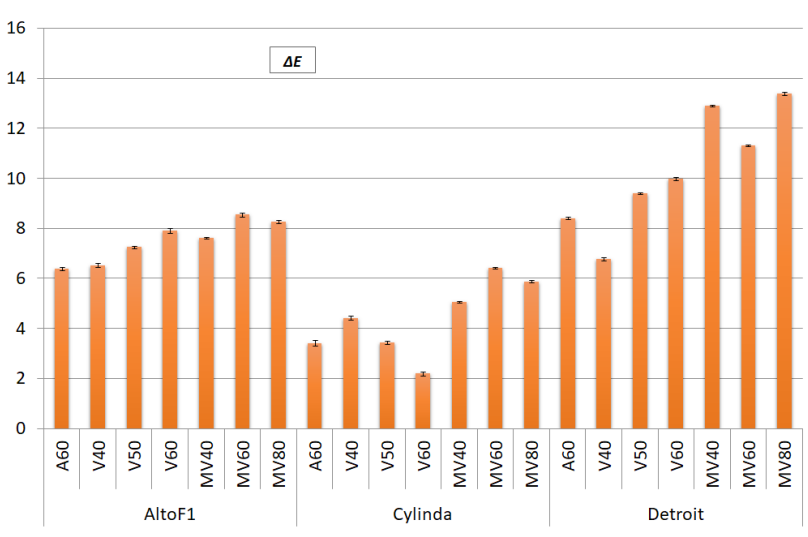

Fig. 1 The color difference parameters on the influence of each drying methods

drying method for all beetroot species in comparison with the other drying methods under investigation (Fig. 2). The Student-T test for total polyphenol content resulted significant difference between the 'AltoF1'-'Cylindra' and 'AltoF1'-'Detroit' beetroot varieties.

The antioxidant capacity (FRAP) values was found to be reduced in all dried beetroot samples (Fig. 3). The microwave vacuum method was found to be the gentlest drying method for this parameter in comparison with the other drying methods under investigation. The 'Cylindra'

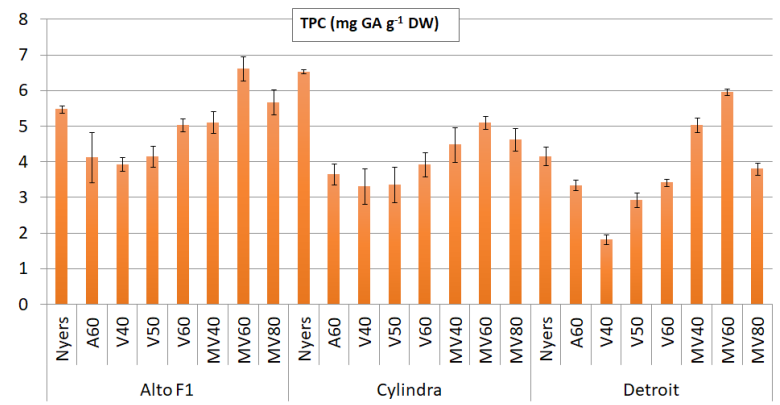

Fig. 2 The effect of different drying methods on total polyphenol content of dried beetroot species

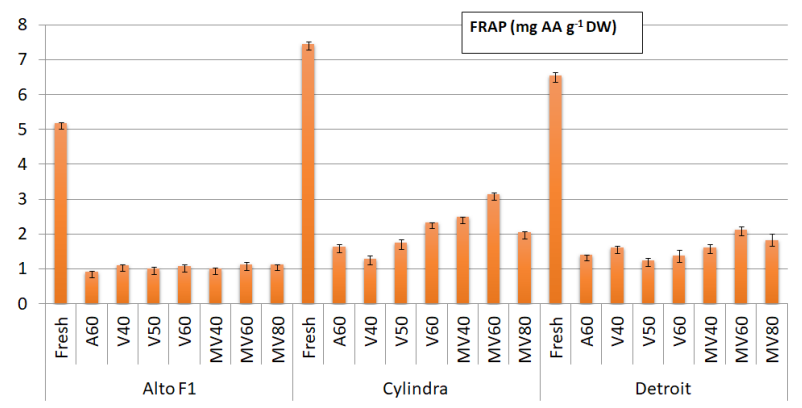

Fig. 3 The effect of different drying methods on the antioxidant capacity of dried beetroot species 
samples dried with microwave vacuum method had significantly higher FRAP values than 'AltoF1' and 'Detroit' beetroots.

The effect of different drying assays on the betacyanin and betaxanthin contents can be seen on the Fig. 4. In all cases, larger amount of these pigments were found to be in the samples dried by vacuum and microwave vacuum than in the samples dried in hot-air. Analyzing average values of the investigated beetroots varieties significant differences $(\mathrm{p}<0.01)$ were found among the 'AltoFl'-'Detroit' and 'Cylindra'-'Detroit' for betacyanin content and among the 'AltoF1'-'Cylindra' for betaxanthin content.

The degradation of betacyanins leads to other phenolic compounds, which simulate the increase of antioxidant activity [17]. As mentioned in others studies the cause of the rising could be due to the compounds released by the mechanical destruction of the cells [18]. Same results were observed in case of sweet potato [19] and peppermint [20]. Ferenczi et al. [3] experienced the antioxidant activity reduced relevantly (from $9.26 \mathrm{mmol}$ Trolox/100 $\mathrm{g}$ dry weight to $4.54 \mathrm{mmol}$ Trolox/100 g dry weight) the effect of microwave vacuum drying for apple products. Nistor et al. [17] measured higher betacyanin, betaxanthin and polyphenol content and antioxidant capacity in the dried red beetroot samples during the free convection at $60{ }^{\circ} \mathrm{C}$ forced convection at $40{ }^{\circ} \mathrm{C}$ at $315 \mathrm{~W}$ power than in case of the convection drying at $70^{\circ} \mathrm{C}$.

Data in Table 2 clarified the effect of different drying methods on each phenolic acids content in dried beet root samples, and found that, the chlorogenic acid concentration slightly reduced for the MV60 and MV80 treatments, but relevantly diminished by the MV40 treatment and that is probably because of the longer drying time. Also, minor differences in the concentration of rutin were found between different drying methods. The hydroxy cinnamic acid concentrations increased while the quercetin concentration decreased in all microwave vacuum drying treatments in all dried beetroot samples.

\subsection{Drying data}

The drying curves of the investigated beetroot species can be seen on the Fig. 5, which shows the differences between the each drying methods. Based on the drying curve of the different beetroot and according to other scientific results [21-23] the microwave drying resulted faster drying compared to the traditional method and it is effective on lower temperature except the MV40 method, where the pre-drying was longer because of the low temperature.

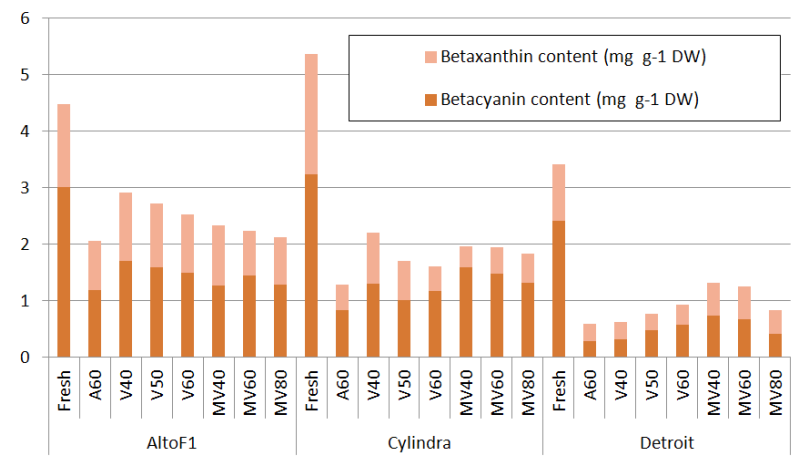

Fig. 4 The effect of different drying methods on the betacyanin and betaxanthin contents of dried beetroot species
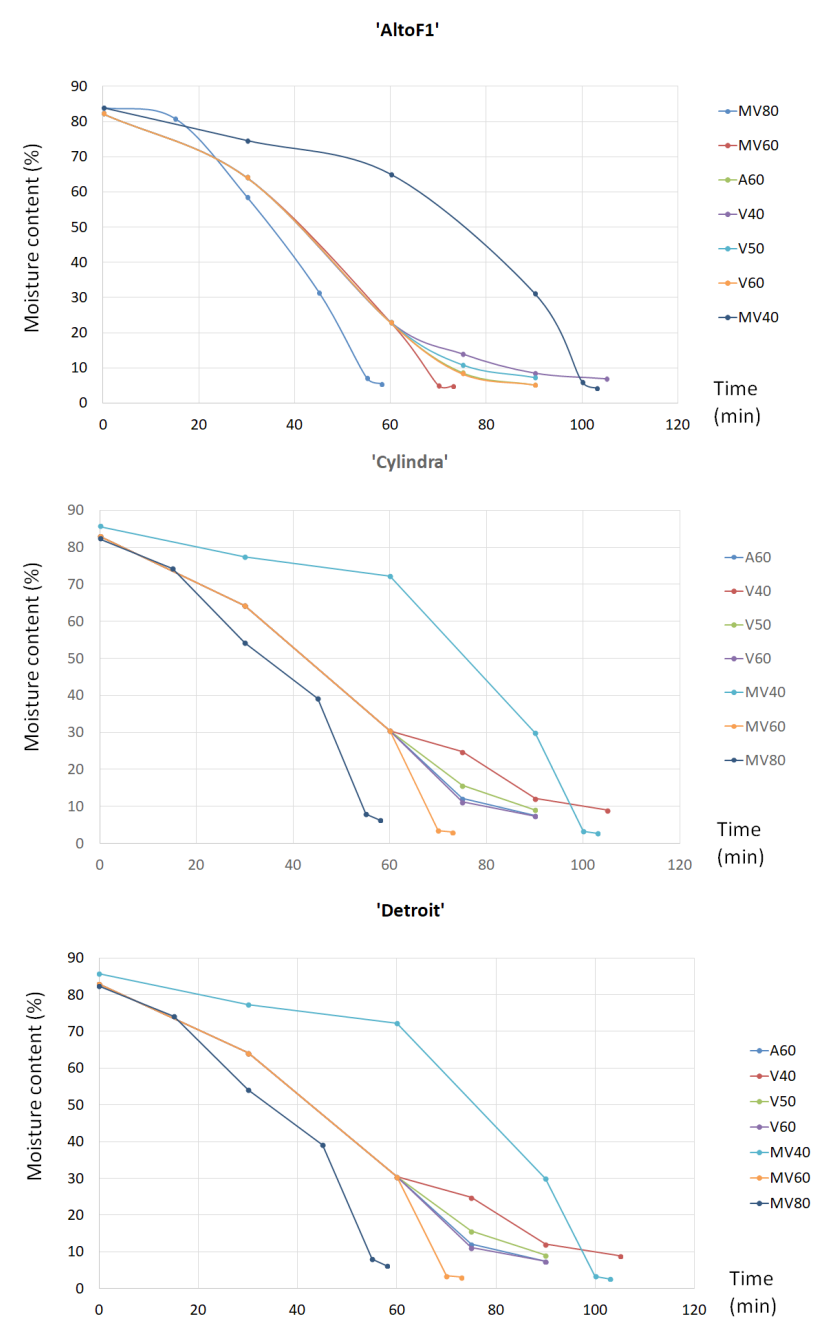

Fig. 5 Drying curves of the investigated beetroot species according to the each drying method

\subsection{Sensory evaluation}

Sensory evaluation results of the 'AltoF1', 'Cylindra' and 'Detroit' dried samples by MV60 treatment are also compiled in profile diagrams (Fig. 6). 
Table 2 Effect of microwave vacuum drying methods on the phenolic acids content of dried beetroot species

\begin{tabular}{|c|c|c|c|c|c|c|c|c|c|}
\hline & & \multicolumn{2}{|c|}{$\begin{array}{l}\text { Chlorogenic acid, } \\
\mathrm{mg} \mathrm{g}^{-1} \mathrm{DW}\end{array}$} & \multicolumn{2}{|c|}{$\begin{array}{c}\text { Rutin, } \\
\mathrm{mg} \mathrm{g}^{-1} \mathrm{DW}\end{array}$} & \multicolumn{2}{|c|}{$\begin{array}{l}\text { Hydroxy cinnamic, acid, } \\
\mathrm{mg} \mathrm{g}^{-1} \mathrm{DW}\end{array}$} & \multicolumn{2}{|c|}{$\begin{array}{l}\text { Quercetin, } \\
\mathrm{mg} \mathrm{g}^{-1} \mathrm{DW}\end{array}$} \\
\hline \multirow{4}{*}{ 'Alto F1' } & Fresh & 0.481 & \pm 0.0061 & 0.123 & \pm 0.0075 & 0.005 & \pm 0.0002 & 0.086 & \pm 0.0044 \\
\hline & MV40 & 0.207 & \pm 0.0021 & 0.095 & \pm 0.0059 & 0.008 & \pm 0.0007 & 0.010 & \pm 0.0005 \\
\hline & MV60 & 0.386 & \pm 0.0040 & 0.187 & \pm 0.0136 & 0.032 & \pm 0.0025 & 0.018 & \pm 0.0014 \\
\hline & MV80 & 0.711 & \pm 0.0046 & 0.136 & \pm 0.0149 & 0.032 & \pm 0.0033 & 0.020 & \pm 0.0024 \\
\hline \multirow{4}{*}{ 'Cylindra' } & Fresh & 0.587 & \pm 0.0045 & 0.127 & \pm 0.0103 & 0.011 & \pm 0.0004 & 0.057 & \pm 0.0020 \\
\hline & MV40 & 0.178 & \pm 0.0017 & 0.157 & \pm 0.0038 & 0.030 & \pm 0.0014 & 0.014 & \pm 0.0016 \\
\hline & MV60 & 0.579 & \pm 0.0049 & 0.109 & \pm 0.0059 & 0.023 & \pm 0.0018 & 0.013 & \pm 0.0025 \\
\hline & MV80 & 0.572 & \pm 0.0035 & 0.091 & \pm 0.0065 & 0.030 & \pm 0.0012 & 0.015 & \pm 0.0013 \\
\hline \multirow{4}{*}{ 'Detroit' } & Fresh & 0.284 & \pm 0.0022 & 0.106 & \pm 0.0059 & 0.010 & \pm 0.0001 & 0.053 & \pm 0.0020 \\
\hline & MV40 & 0.295 & \pm 0.0177 & 0.194 & \pm 0.1334 & 0.036 & \pm 0.0033 & 0.015 & \pm 0.0012 \\
\hline & MV60 & 0.515 & \pm 0.0132 & 0.079 & \pm 0.0050 & 0.025 & \pm 0.0022 & 0.030 & \pm 0.0006 \\
\hline & MV80 & 0.660 & \pm 0.0053 & 0.076 & \pm 0.0037 & 0.014 & \pm 0.0019 & 0.012 & \pm 0.0010 \\
\hline
\end{tabular}

It can be seen that, the sensory profile of 'Cylindra' and 'Detroit' samples are similar. Statistically, there was no significant difference on the sweet taste, but on the diagram, it is visible that 'Cylindra' slices had the sweetest taste. Also, according to the statistical calculation of the sensory evaluation there were significant differences in the hue (0.0275), the color homogeneity (0.0001), the sweet scent (0.0362), in the crunchiness $(0.0005)$ and in the global taste intensity $(0.0139)$ between the dried beetroot species.

\section{Conclusion}

This series of measurement was carried out in order to obtain comparative result for drying of different beetroot species under variable conditions.

During the application of the different drying methods the moisture content below $10 \%$ was reached the earliest by the combined methods with hot-air followed by microwave vacuum finish drying. However, the microwave vacuum drying methods resulted greater changes in color of

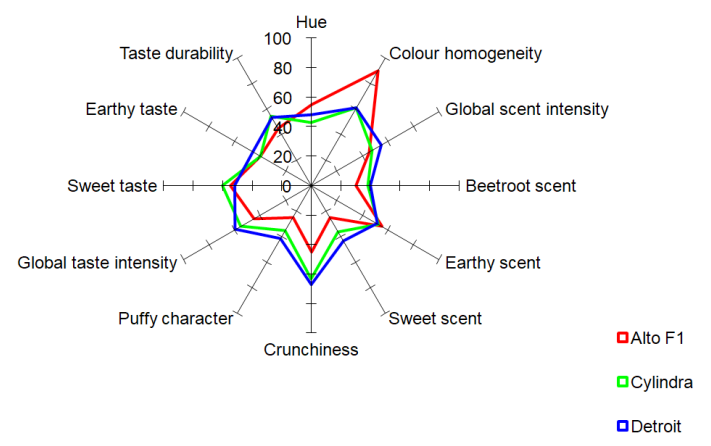

Fig. 6 Sensory evaluation of the dried beetroot species using MV60 treatment dried beetroots than the convection and vacuum drying, but according to the investigated parameters the microwave vacuum drying proved gentler than the atmospheric and vacuum drying. Based on total polyphenol contents, antioxidant capacities and betacyanin, betaxanthin contents, it could be concluding that the microwave vacuum drying pre-treatment at $60^{\circ} \mathrm{C}$ can be used for preservation of beetroot slices with retention of high quality. During the statistical evaluation of physicochemical parameter it can been established the 'Cylindra' samples were the most appropriate beetroot variety for microwave vacuum drying.

Also, according to the statistical analysis of the sensory evaluation for the microwave vacuum drying pre-treatment at $60{ }^{\circ} \mathrm{C}$ there were differences in the most investigated parameters between the different dried beetroot species which verifies the importance of choice of beetroot species.

Based on the results a 'Cylindra' species was the most suitable beetroot variety for drying. This study confirmed that using microwave vacuum drying shortens the time and improves the quality of the product.

As a continuation of the experiment it is advisable to carry out the tests with additional sizes, and using additional consumer surveys to determine the parameters of the most marketable product so this product with a special texture can be marketed as a functional food for the shelves of the stores.

\section{Acknowledgements}

This work was supported by Felsőoktatási Intézményi Kiválósági Program - 1783-3/2018/FEKUSTRAT and Élelmiszertudományi Doktori Iskola - Doctoral school ID: 232. EFOP-3.6.3-VEKOP-16-2017-00005. 


\section{References}

[1] Scaman, C. H., Durance, T. D. "19 - Combined Microwave Vacuum-drying", In: Sun, D.-W. (ed.) Emerging Technologies for Food Processing, 1st ed., Academic Press, Cambridge, USA, 2005, pp. 507-533.

https://doi.org/10.1016/B978-012676757-5/50021-9

[2] Kowalski, S. J., Mierzwa, D. "Convective Drying in Combination with Microwave and IR Drying for Biological Materials", Drying Technology, 27(12), pp. 1292-1301, 2009. https://doi.org/10.1080/07373930903207712

[3] Ferenczi, S., Cserhalmi, Zs., Visnyei, B., Szücs, V., Czukor, B. "Effect of operational parameters of microwave vacuum drying combined with hot-air pre-drying to physical, sensory, and nutritional properties of dried apple snack", Acta Alimentaria, 46(2), pp. 152-161, 2017. https://doi.org/10.1556/066.2016.0005

[4] Marfil, P. H. M., Santos, E. M., Telis, V. R. N. "Ascorbic acid degradation kinetics in tomatoes at different drying conditions", LWT - Food Science and Technology, 41(9), pp. 1642-1647, 2008. https://doi.org/10.1016/j.lwt.2007.11.003

[5] Chua, K. J., Mujumdar, A.S., Chou, S.K., Hawlander, M. N. A., Ho, J. C. "Convective drying of banana, guava and potato pieces: Effect of cyclical variations of air temperature on drying kinetics and color change”, Drying Technology, 18(4-5), pp. 907-936, 2000. https://doi.org/10.1080/07373930008917744

[6] Szűcs, V., Szabó, E., Ferenczi, S., Cserhalmi, Zs. "Mikrohullámú vákuumszárítással készült alma termékek fogyasztói kedveltségének vizsgálata conjoint elemzés alapján" (Consumer preference of microwave vacuum dried apple products with conjoint analysis), Élelmiszer Tudomány Technológia, 59(1), pp. 7-13, 2015.

[7] Ferenczi, S., Czukor, B., Cserhalmi, Zs. "Evaluation of Microwave Vacuum Drying Combined with Hot-Air Drying and Compared with Freeze- and Hot-Air Drying by the Quality of the Dried Apple Product", Periodica Polytechnica Chemical Engineering, 58(2), pp. 111-116, 2014.

https://doi.org/10.3311/PPch.7082

[8] Dermelj, M., Bogenrieder, C., Hidvégi, M., Lásztity, R. "Effect of microwave vacuum drying on protein and chlorophyll contents of blind nettle (Urtica urens L.)", Periodica Polytechnica Chemical Engineering, 39(1), 77-84, 1995. [online] Available at: https:// pp.bme.hu/ch/article/view/2597 [Accessed: 22 March 2018]

[9] Ferenczi, S, Czukor, B., Cserhalmi, Zs. "Légárammal kombinált mikrohullámú vákuumszárítás II. Jonatán alma légáramú előszárítással kombinált mikrohullámú vákuumszárítási kísérletei" (Combined air- and microwave-vacuum drying II.), Élelmiszer Tudomány Technológia, 65(2), pp. 15-20, 2011. (in Hungarian)

[10] Singleton, V. L., Rossi, J. A. "Colorimetry of Total Phenolics with Phosphomolybdic-Phosphotungstic Acid Reagents", American Journal of Enology and Viticulture, 16(3), pp. 144-158, 1965.

[11] Benzie, I. F. F., Strain, J. J. " The Ferric Reducing Ability of Plasma (FRAP) as a Measure of "Antioxidant Power": The FRAP Assay", Analytical Biochemistry, 239(1), pp. 70-76, 1966. https://doi.org/10.1006/abio.1996.0292

[12] Castellar, R., Obón, J. M., Alacid, M., Fernández-López, J. A. "Color Properties and Stability of Betacyanins from Opuntia Fruits", Journal of Agricultural and Food Chemistry, 51(9), pp. 2772-2776, 2003. https://doi.org/10.1021/jf021045h
[13] Stintzing, F. C., Herbach, K. M., Mosshammer, M. R., Carle, R., Yi, W., Sellappan, S., Akoh, C. C., Bunch, R., Felker, P. "Color, Betalain Pattern, and Antioxidant Properties of Cactus Pear (Opuntia spp.) Clones", Journal of Agricultural and Food Chemistry, 53(2), pp. 442-451, 2005.

https://doi.org/10.1021/jf048751y

[14] Székely, D., Szalóki-Dorkó, L., Stéger-Maté, M., Szabó-Nótin, B., Ivanics, J., Monspart-Sényi, J. "Distribution of antioxidant components in roots of different red beets (Beta vulgaris L.) cultivars", Acta Alimentaria, 43(Suppl. 1), pp. 164-171, 2014. https://doi.org/10.1556/AAlim.43.2014.Suppl.23

[15] Kókai, Z., Henze, E., Heszberger, J., Kápolna, B., Szabó, R. "IT support for exploring sensory quality of sustainably grown apple varieties", In: 4th EFITA Conference, Debrecen, Hungary, 2003, pp. 632-640.

[16] Musielak, G., Kierca, A. "Influence of Varying Microwave Power during Microwave-Vacuum Drying on the Drying Time and Quality of Beetroot and Carrot Slices", Drying Technology, 32(11), pp. 1326-1333, 2014. https://doi.org/10.1080/07373937.2014.924135

[17] Nistor, O.-V., Seremet, L., Andronoiu, D. G., Rudi, L., Botez, E. "Influence of different drying methods on the physicochemical properties of red beetroot (Beta vulgaris L. var Cylindra)", Food Chemistry, 236, pp. 59-67, 2017.

https://doi.org/10.1016/j.foodchem.2017.04.129

[18] Stinco, C. M., Fernández-Vázquez, R., Escudero-Gilete, M. L., Heredia, F. J., Meléndez-Martínez, A. J., Vicario, I. M. "Effect of Orange Juice's Processing on the Color, Particle Size, and Bioaccessibility of Carotenoids", Journal of Agricultural and Food Chemistry, 60(6), pp. 1447-1455, 2012.

https://doi.org/10.1021/jf2043949

[19] Yang, J., Chen, J.-F., Zhao, Y., Mao, L.-C. "Effects of Drying Processes on the Antioxidant Properties in Sweet Potatoes", Agricultural Sciences in China, 9(10), pp. 1522-1529, 2010. https://doi.org/10.1016/S1671-2927(09)60246-7

[20] Uribe, E., Marín, D., Vega-Glávez, A., Quispe-Fuentes, I., Rodríguez, A. "Assessment of vacuum-dried peppermint (Mentha piperita L.) as a source of natural antioxidants", Food Chemistry, 190, pp. 559-565, 2016. https://doi.org/10.1016/j.foodchem.2015.05.108

[21] Andrés, A., Bilbao, K., Fito, P. "Drying kinetics of apple cylinders under combined hot air - microwave dehydration", Journal of Food Engineering, 63(1), pp. 71-78, 2004. https://doi.org/10.1016/S0260-8774(03)00284-X

[22] Kaur, K., Singh, A. K. "Drying kinetics and quality characteristics of beetroot slices under hot air followed by microwave finish drying", African Journal of Agricultural Research, 9(12), pp. 10361044, 2014. https://doi.org/10.5897/AJAR2013.7759

[23] Wojdyło, A., Figiel, A., Lech, K., Nowicka, P., Oszmiański, J. " Effect of Convective and Vacuum-Microwave Drying on the Bioactive Compounds, Color, and Antioxidant Capacity of Sour Cherries", Food \& Bioprocess Technology, 7(3), pp. 829-841, 2014. https://doi.org/10.1007/s11947-013-1130-8 